\title{
The Death Penalty in Post-Independence Ireland
}

\section{David M. Doyle \& Ian O'Donnell}

To cite this article: David M. Doyle \& lan O'Donnell (2012) The Death Penalty in Post-Independence Ireland, The Journal of Legal History, 33:1, 65-91, DOI: 10.1080/01440365.2012.661141

To link to this article: https://doi.org/10.1080/01440365.2012.661141

册 Published online: 28 Mar 2012.

Submit your article to this journal ๔

Џll Article views: 357

4 Citing articles: 4 View citing articles ๘ 


\title{
The Death Penalty in Post-Independence Ireland
}

\author{
DAVID M. DOYLE AND IAN O'DONNELL
}

The history of capital punishment in post-Independence Ireland has received scant scholarly attention. This essay is an attempt to set out what can be learned about the executed persons, the executioners, and the politicians whose inaction (not reforming the law) and actions (deciding against clemency) brought the two former groups together. The death penalty was deployed strategically against IRA members during the early 1940s as part of a package of legal measures designed to crush subversive activity, but more usually its targets were murderers whose acts had no wider ramifications. One notable aspect of the Irish arrangements was that when a prisoner was to be taken to the gallows an English hangman was always contracted to arrange the 'drop'. Reflecting popular antipathy towards the practice the Irish state was unable to find a willing executioner within its borders.

\section{INTRODUCTION}

I am most definitely of the opinion that the prestige of Eire would be enormously enhanced if the Death Penalty were abolished as one of the first acts of the new Regime ... If as a result of this letter steps be taken to break away from one of the legacies left by England and an advance made to make Our beloved country more truly Christian I believe that she may well be on the way to once more deserve the title of the Island of Saints. ${ }^{1}$

Independence from Britain presented an opportunity for Ireland to break the historic link with capital punishment. When Dáil Éireann narrowly ratified the Anglo-Irish Treaty in January 1922, 'one of earliest acts of the Provisional Government' was to establish a committee to draft a Constitution for the Irish Free State. ${ }^{2}$ Hampered by

Dr David M. Doyle, Institute of Criminology, University College Dublin. Email: doyle.david@ucd.ie Professor Ian O’Donnell, Institute of Criminology, University College Dublin. Email: ian.odonnell@ucd.ie For their advice and practical assistance we are grateful to Tom Behan, Tim Carey, Tim Pat Coogan, Steve Fielding, Victor Laing, Stewart McLaughlin, Grainne O’Meara and Sean Reynolds.

${ }^{1}$ Letter from J.H. Blackwood Murphy to Douglas Hyde, 23 Feb. 1949, National Archives of Ireland (NAI), DT S7788B.

${ }^{2}$ B. Farrell, 'The Drafting of the Free State Constitution: I', 5 The Irish Jurist (1970), 117. See also B. Farrell, 'The Drafting of the Free State Constitution: II', 5 The Irish Jurist (1970), 343-356. On the events surrounding the formation of the Irish Free State, see J. Regan, The Irish Counter-Revolution, 1921-1936: Treatyite Politics and Settlement in Independent Ireland, Dublin, 1999.

The Journal of Legal History, Vol. 33, No. 1, April 2012, pp. 65-91 
the bitter legacy of the Treaty, the drafting committee comprised three groups, one of which placed the question of capital punishment on the agenda. ${ }^{3}$ 'The penalty of death', draft B specified, 'shall not be attached to any offence'. 4 Although the flame of abolition appears to have been ignited by James Green Douglas, a prominent Quaker, others involved in the drafting process also exhibited abolitionist tendencies. Michael Collins, chairman of the Provisional Government, purportedly 'expressed agreement with the proposal to abolish capital punishment', declaring that we 'had enough executions in Ireland, and that it would be a good thing to see the end of them'. 5 George O'Brien, barrister and later professor of economics at the National University of Ireland, was 'personally in favour of the abolition of the death sentence', but counselled at the time that it was 'a matter which should be left to legislation in the Oireachtas [parliament] ${ }^{6}$ Accordingly the provision in draft B did not find its way into the final version of the 1922 Constitution.

The recommendation to abolish capital punishment by legislation - which, in the event, was not acted upon by the fledgling Free State - was grounded in pragmatic concerns. An act of parliament could, after all, have been repealed at the discretion of the legislature, whereas amending the Constitution to reintroduce capital punishment would have proved more difficult to effect, especially post-1930 when any amendment would need to have been accomplished by referendum. ${ }^{7}$ As popular support for judicial execution was far from assured, the government would have had little alternative but to risk going to the people if it wished, on some future occasion, to return to the status quo ante. A memorandum for government drafted several decades later gave the following view: 'If the question had been put to a plebiscite when we obtained control of our own affairs we would not have retained the death penalty which is naturally abhorrent to the Irish people'. ${ }^{8}$

Capital punishment was not 'adopted uncritically at the time of the establishment of the State when we took over the whole body of British law' ${ }^{9}$ Clearly there was a deliberative process underway - albeit an inconsequential one - which resulted in the death penalty being retained after Independence. ${ }^{10}$ Additionally, the descent into civil war (1922-23) led the government as a 'matter of military necessity' to introduce the

\footnotetext{
${ }^{3}$ For details of the membership of these groups (or 'factions') see G. O'Brien, 'Capital Punishment in Ireland', in N.M. Dawson, ed., Reflections on Law and History, Dublin, 2006, 225-226.

${ }^{4}$ B. Farrell, 'The Drafting of the Free State Constitution: III', 6 The Irish Jurist (1971), 123.

${ }^{5}$ J.A. Gaughan, ed., The Memoirs of Senator James G. Douglas (1887-1954): Concerned Citizen, Dublin, 1998, 86-87.

${ }^{6}$ B. Farrell, 'The Drafting of the Free State Constitution: IV', 6 The Irish Jurist (1971), 359.

${ }^{7}$ Article 50 of the 1922 Constitution specified that, after the expiration of a period of eight years from the date of the coming into operation of the Constitution, any amendment would have to have been submitted to a referendum of the people and could no longer be made by way of ordinary legislation.

${ }^{8}$ Department of Justice, Memorandum for Government, 12 April 1956, NAI, DT S7788B.

${ }^{9}$ Ibid. For a review of the role and relevance of the death penalty in Britain during the first half of the twentieth century see Royal Commission on Capital Punishment (1949-53), Report [Cmd. 8932], London, 1953.

${ }^{10}$ The abolitionist argument had been made occasionally in the pre-Independence period, but cautiously and without effect. According to W.E. Vaughan (Murder Trials in Ireland, 1836-1914, Dublin, 2009, 317): 'When abolitionists did appear they were not only small in numbers, but diffident. In 1841 a memorial from the Hibernian Anti-Punishment By Death Society made it clear that they did not expect much notice to be taken of their efforts ... Irish abolitionists were not prominent among the witnesses who
} 
Army Emergency Powers Resolution. ${ }^{11}$ Trials which resulted in death sentences were held before military courts that afforded few due process rights. These 'courts' or 'committees' sanctioned the execution by firing party of eighty-one anti-Treaty prisoners (later eulogised erroneously as 'the 77') between November 1922 and May $1923,{ }^{12}$ including the summary executions of four senior republicans 'without any pretence of legality'. ${ }^{13}$ The majority of these men were executed for the possession of arms and ammunition without proper authority. With "conditions bordering on anarchy', ${ }^{14}$ some carried unauthorised arms and killed for political purposes, some committed robbery and arson, while others took advantage of the situation to avenge perceived wrongs and settle old scores. In such circumstances it became increasingly difficult, as O'Brien observed, to distinguish between 'civilian' and political offences. ${ }^{15}$

A covert decision may, as Garvin surmised, have been made by the Free State Government in the aftermath of the civil war (and possibly communicated informally to Anti-Treatyites) that the courts would not pursue acts of theft and murder that had occurred during the period between 6 December 1921 and 27 April 1923, ${ }^{16}$ but there is little doubt that the Dublin Commission established in October 1923 aimed, as the Irish Independent intimated, to restore faith in the impartiality and effectiveness of political, legal and judicial institutions:

The convictions secured and the exemplary sentences imposed at the Commission are more potent in stamping out crime and restoring order than anything that has occurred in recent years. All persons disposed to indulge in crime must now be convinced that there is in this country an Executive authority strong enough and sufficiently equipped to trace criminals and bring them to justice. ${ }^{17}$

But why, given its historical resonance as a manifestation of English tyranny, and its divisive civil war connotations, did the death penalty continue to constitute an 'exemplary' sentence in post-civil war Ireland, remaining on the statute book as the mandatory penalty for murder for over forty years? Why was the abolitionist debate not rekindled for so long, despite occasional ripples of concern? ${ }^{18}$ The answer to this question has two parts, each of which contains within it a puzzle.

First of all, capital punishment was routinely held out as a vital safeguard against subversion. Successive governments justified its retention on the basis that

gave evidence to the 1866 royal commission'. See also J. Haughton, 'On Death Punishments', A Paper Read before the Dublin Statistical Society, Dublin, 1850, 3-11.

${ }^{11}$ O'Brien, 'Capital Punishment', 226-227.

${ }^{12}$ Executions by Provisional and Irish Free State Governments, 1922-24, 19 Aug. 1948, NAI, DT S1884. See also C. Campbell, Emergency Law in Ireland, 1918-1925, Oxford, 1994, 361-371.

${ }^{13}$ E. O'Halpin, Defending Ireland: The Irish State and its Enemies since 1922, Oxford, 1999, 34.

${ }^{14}$ M. Hopkinson, Green against Green: The Irish Civil War, Dublin, 1992, 263.

${ }^{15}$ O'Brien, 'Capital Punishment', 226.

${ }^{16}$ T. Garvin, 1922: The Birth of Irish Democracy, Dublin, 1988, 166.

${ }^{17}$ Irish Independent, 30 Nov. 1923, 6. For details on the Dublin Criminal Commission see Irish Law Times and Solicitors' Journal, 27 Oct. 1923, 264 and Irish Law Times and Solicitors' Journal, 1 Dec. 1923, 296297.

${ }^{18}$ See O’Brien, 'Capital Punishment', 223-258. 
politically-motivated crimes were the product of a decision-making calculus that was likely to give significant weight to the threat of death; this set them apart from the wider class of killings which were impulsive, emotional and fuelled by alcohol. ${ }^{19}$ But the puzzle here is that the vast majority of executions involved killings that had no conceivable political dimension and yet a situation was allowed to persist where capital punishment was mandatory for all murders. In addition, while the government of the day could have spared any condemned person from death, they chose not to do so on thirty-five occasions between 1923 and 1954, all but six of which involved non-political actors. ${ }^{20}$

Furthermore, while governments justified the retention of capital punishment due to the risk posed by the IRA, simultaneously they railed at the ineffectiveness of the ordinary criminal courts. To deal with the perceived threat, emergency legislation and special tribunals were introduced. In other words, when it came to dealing with the integrity of the state the political refrain was typically that the criminal justice system was inadequate to the task and that extraordinary measures were required. ${ }^{21}$ There was a troubling inconsistency here too. During the period in which Eamon De Valera's government sanctioned the execution of six IRA men in the Free State, he lobbied (unsuccessfully) for the reprieve of Republicans awaiting death in Northern Ireland and Britain. ${ }^{22}$

Secondly, the unwillingness to do away with capital punishment was influenced by the slide into civil war. In this context the state was reluctant to do anything that might have been seen as a sign of weakening resolve; any such indication would risk giving succour to its enemies. The puzzle here is that Eamon De Valera, the Taoiseach [prime minister] whose government used the ultimate sanction most frequently, had himself been sentenced to death in 1916, an experience that might have been expected to temper his willingness to permit his countrymen to face the hangman or a firing party. ${ }^{23}$ In addition he, together with other ministers and Taoisigh who were prepared to allow executions go ahead, had been comrades with men executed during the revolutionary period. They could have been expected to know that in the case of political prisoners the consequences of an execution, if viewed as illegitimate by the public, could be socially destabilising, and in nonpolitical cases the international trend was towards abolition.

\footnotetext{
${ }^{19}$ I. O'Donnell, 'Killing in Ireland at the Turn of the Centuries: Contexts, Consequences and Civilizing Processes', 37 Irish Economic and Social History (2010), 53-74.

${ }^{20}$ For information on the location of the clemency power pre-1937 see, Extract from Instructions Passed under the Royal Sign Manual and Signet to the Governor-General of the Irish Free State, 6 Dec. 1922, NAI DT, S7788A. See also Death Sentences Procedure File, 20 May 1935, NAI, DT S7788A.

${ }^{21}$ Emergency provisions introduced for a specific purpose during a particular crisis can become part of the routine apparatus of criminal justice; a process known as 'normalisation'. See B. Vaughan and S. Kilcommins, Terrorism, Rights and the Rule of Law: Negotiating Justice in Ireland, Cullompton, 2008, 67-96.

${ }^{22}$ The Earl of Longford and T.P. O'Neill, Eamon De Valera, Boston, 1971, 359; T.P. Coogan, The IRA, London, 1995, 180; J. Maguire, IRA Internments and the Irish Government: Subversives and the State 1939-1962, Dublin, 2008, 24.

${ }^{23}$ Sixteen executions occurred under the Cumann na nGaedheal government of 1923-32; seventeen under Fianna Fáil, 1932-48; one under the first Interparty Government, 1948-51; and one under Fianna Fáil, 1951-54.
} 
There is one final curiosity: despite retaining the death penalty, it did not prove possible to find a willing executioner within the country. When the need arose, one or other of the Pierrepoints travelled across the Irish Sea to place the noose around the condemned person's neck. The fact that external assistance was required for this gruesome purpose speaks volumes about the level of public antipathy and unease (perhaps even revulsion) towards the practice. This disquiet may also be reflected in the fact that despite the vibrancy of historical scholarship in Ireland, and the large volume of international literature around the death penalty, this is an area of inquiry that has, thus far, attracted little attention.

It is generally accepted that the recognition of the death penalty as a human rights issue, combined with the development of international human rights law and the political weight given to the abolition campaign led by European institutions, were instrumental in the surge in abolition across Europe in the second half of the twentieth century. ${ }^{24}$ In 1962, the Ancel Report pointed out that most European countries had followed the path of 'abolition by stages': first a reduction in the range of crimes legally punishable by death until only murder and (sometimes) treason were left, then systematic use of commutation, leading to de facto abolition, and eventually abolition de jure. ${ }^{25}$ This describes the trajectory in post-Independence Ireland. As the Minister for Justice stated in 1956, he was impressed by the case 'for not formally abolishing (or suspending) capital punishment at all but letting it fall into disuse instead' ${ }^{26}$

The aim of this essay is not to provide a history of the abolition movement in Ireland, but rather to scrutinise the historical context in which thirty-four men and one woman paid the ultimate price for their crimes after Independence. The spate of civil war executions is omitted from the analysis on account of their political nature and the fraught circumstances that attended them. The approach taken in what follows is to set out what can be learned about the various dramatis personae, namely the executed persons, the executioners and the politicians whose inaction (not reforming the law) and actions (deciding against clemency) brought the two former groups together. Hopefully, this will clarify our understanding of an aspect of twentieth-century Ireland that has remained in the shadows. First we turn our attention to the men (and woman) for whom the state could find no reason to be merciful.

\section{EXECUTED PERSONS}

Looking at the demographic characteristics of persons executed between November 1923 and April 1954 (see Table 1), their average age at death was thirty-one years (range: 19-48). Nine carried out their crimes in Dublin but there was a wide geographical spread, with seventeen (of twenty-six) counties being the locations for killings that led to an execution. The weaponry used included guns, hatchets and blunt instruments, and the occupations of the protagonists reflected the

\footnotetext{
${ }^{24} \mathrm{R}$. Hood and C. Hoyle, The Death Penalty: A Worldwide Perspective, 4th ed., Oxford, 2008.

${ }^{25}$ M. Ancel, The Death Penalty in European Countries, Strasbourg, 1962; United Nations, Capital Punishment, New York, 1968.

${ }^{26}$ Memorandum for Government, 12 April 1956, NAI S7788B.
} 
TABLE 1

EXECUTED PERSONS

\begin{tabular}{|c|c|c|c|c|c|c|}
\hline & Age & Occupation & Weapon & Location & Date of crime & Executed \\
\hline William Downes & 24 & Despatch rider in National Army & Revolver & Dublin & 19 Oct. 1923 & 29 Nov. 1923 \\
\hline Thomas Delaney & 38 & Labourer & Broken tongs, slasher, brick & Offaly & 27 Jun. 1923 & 12 Dec. 1923 \\
\hline Thomas McDonagh & 43 & Farmer & Shotgun & Roscommon & 25 May 1922 & 12 Dec. 1923 \\
\hline Peter Hynes & 40 & Labourer & Iron bar & Louth & 15 Jan. 1922 & 15 Dec. 1923 \\
\hline Jeremiah Gaffney & 23 & Free State Army & Revolver & Kerry & 6 Dec. 1923 & 13 March 1924 \\
\hline Felix McMullen & 26 & Former captain in National Army & Revolver & Wicklow & 21 Jan. 1924 & 1 Aug. 1924 \\
\hline Cornelius O'Leary & 40 & Farm labourer & Hatchet & Cork & 26 Feb. 1924 & 28 July 1925 \\
\hline Michael Talbot & 23 & Labourer & Hatchet & Limerick & 24 Oct. 1924 & 5 Aug. 1925 \\
\hline Annie Walsh & 31 & Wife of farm labourer & Hatchet & Limerick & 24 Oct. 1924 & 5 Aug. 1925 \\
\hline James Myles & 22 & Labourer & Gun & Louth & 27 Feb. 1924 & 15 July 1926 \\
\hline James McHugh & 31 & Farm labourer & Last & Wexford & 24 April 1926 & 22 Nov. 1926 \\
\hline Henry McCabe & 48 & Gardener & Blunt instrument & Dublin & 31 March 1926 & 9 Dec. 1926 \\
\hline William O'Neill & 19 & Casual labourer & Hand or stick & Wicklow & 8 May 1927 & 29 Dec. 1927 \\
\hline Gerard Toal & 20 & Chauffeur & Undetermined (body dismembered) & Louth & 16 May 1927 & 29 Aug. 1928 \\
\hline John J. Cox & 33 & Labourer & Iron bar & Clare & 21 Dec. 1928 & 25 April 1929 \\
\hline David O'Shea & 33 & Farm labourer & Blunt instrument & Cork & 8 Feb. 1931 & 4 Aug. 1931 \\
\hline Patrick McDermott & 28 & Farmer & Gun & Roscommon & 3 Sept. 1932 & 29 Dec. 1932 \\
\hline John Fleming & 31 & Draper's assistant & Blunt instrument & Dublin & 26 July 1933 & 5 Jan. 1934 \\
\hline John Hornick & 36 & Farmer & Stock of gun & Wexford & 25 Jan. 1937 & 17 June 1937 \\
\hline Dermot Smyth & 33 & Farmer & Shotgun & Leix & 17 Aug. 1938 & 7 Jan. 1939 \\
\hline Patrick McGrath & 46 & Director of training (IRA) & Revolver & Dublin & 16 Aug. 1940 & 6 Sept. $1940^{*}$ \\
\hline Thomas Green & 25 & Unspecified (IRA) & Submachine gun & Dublin & 16 Aug. 1940 & 6 Sept. $1940^{*}$ \\
\hline Daniel Doherty & 29 & Farmer & Blunt instrument, strangulation & Donegal & 19 Sep 1940 & 7 Jan 1941 \\
\hline Henry Gleeson & 38 & Farm labourer & Shotgun & Tipperary & 20 Nov. 1940 & 23 April 1941 \\
\hline Patrick Kelly & 31 & Labourer & Strangulation, drowning & Sligo & 17 April 1941 & 18 Dec. 1941 \\
\hline Richard Goss & 26 & Shoe machinist (IRA) & Revolver & Longford & 18 July 1941 & 9 Aug. 1941* \\
\hline Maurice O'Neill & 25 & Carpenter (IRA) & Revolver & Dublin & 24 Oct. 1942 & 12 Nov. $1942^{*}$ \\
\hline George Plant & 38 & Motor mechanic (IRA) & Revolver & Tipperary & 28 Sept. 1940 & 5 March $1942 *$ \\
\hline Bernard Kirwan & 34 & Farmer's son & Undetermined (body dismembered) & Offaly & 22 Nov. 1941 & 2 June 1943 \\
\hline William O'Shea & 23 & Labourer & Not known & Waterford & 15 March 1943 & 12 Aug. 1943 \\
\hline Charles Kerins & 26 & Unspecified (IRA) & Automatic pistol & Dublin & 9 Sept. 1942 & 1 Dec. 1944 \\
\hline James Lehman & 40 & Canadian ex-soldier & Cyanide poisoning & Dublin & 19 March 1944 & 19 March 1945 \\
\hline Joseph McManus & 41 & Builder's labourer & Shotgun & Meath & 6 Oct. 1946 & 3 March 1947 \\
\hline William Gambon & 28 & No occupation & Iron bar & Dublin & 22 Aug. 1948 & 28 Nov. 1948 \\
\hline Michael Manning & 24 & Carter & Strangulation, suffocation & Limerick & 18 Nov. 1953 & 20 April 1954 \\
\hline
\end{tabular}

* Executed by firing party 
socioeconomic circumstances of the time, with many working the land for a (meagre) living. Six were executed for their involvement in activities carried out on behalf of the IRA and not all of them had used lethal violence; Richard Goss and Maurice O'Neill had been convicted of offences 'which did not involve actual loss of life'. ${ }^{27}$ Five of the IRA men were dealt with by 'military courts' and the method of execution in these cases was by firing party, the executioners being drawn from the ranks of the Irish army. ${ }^{28}$ Charles Kerins had a different fate. Convicted by the Special Criminal Court rather than a military tribunal, he was hanged rather than shot. The governor of Mountjoy Prison paid Kerins the grim tribute of being 'the bravest man' he 'ever saw die by hanging'. 29

William Downes was the first person to be hanged in the Free State. A despatch rider in the National Army, Downes and two other soldiers robbed the office of a candle factory in County Dublin, taking $£ 40$ and a number of bicycles. As they cycled away they were pursued by three detectives. Downes was arrested and placed in a police car guarded by Captain Fitzgerald, while the pursuit of the others continued. Downes waited for Fitzgerald's attention to be distracted and shot him dead before making his escape. He was arrested at his home later that evening and tried at the Dublin Commission. ${ }^{30}$ Found guilty, he was executed in Mountjoy Prison on 29 November 1923.

Not all killings were motivated by a desire for material gain. A number involved domestic disputes and several were characterised by a high level of sexual violence. The killing perpetrated by David O'Shea in February 1931 involved a sexual attack that continued after the victim's death. During his charge to the jury Mr Justice Hanna introduced the term 'necrophilia' into the Irish law reports:

The most extreme form of this terrible disease ['lust murder'] is known as 'necrophilia,' in which the sexual maniac prefers the dead or dying body to the living body for his lust. I have never known in my long experience of criminal Courts - an experience extending to thirty-one years ... - a more perfect example of what is known to the scientist as 'necrophilia'. It is the extremest form of this crime. It was [sic] the extremest form of that depravity. You and I may think these people mad, but in law they are not mad. They are considered sane and dangerous animals. ${ }^{31}$

The jury added a rider to its verdict declaring that it was 'an unpremeditated crime, committed during a period of mental abnormality', and strongly recommended that 'special consideration be given to this factor' ${ }^{32}$ This plea failed to influence the

\footnotetext{
${ }^{27}$ Considerations submitted to the Government as to why the Sentence of Death passed on Richard Goss by a Military Court sitting at Collins Barracks in the City of Dublin on the 1st day of August 1941 should not be Carried Out, 2 Aug. 1941, NAI, DT 12540.

${ }^{28}$ Patrick McGrath, Thomas Green and Maurice O'Neill were shot in Mountjoy Prison. George Plant and Richard Goss were shot in Portlaoise Prison.

${ }^{29}$ Cited in S. Cronin, Washington's Irish Policy 1916-1986, Dublin, 1987, 103.

${ }^{30}$ Irish Times, 27 Oct. $1923,8$.

${ }^{31}$ Court of Criminal Appeal, No. 16 of 1931, 11 June 1931; See also Attorney General v O'Shea, [1931] IR, $724-725$.

${ }^{32}$ Attorney General v O'Shea, [1931] IR, 713.
} 
Executive Council, which reaffirmed the mandatory death sentence for a sexuallymotivated homicide for the second time in less than four years. In December 1927, nineteen-year-old William O'Neill had been executed for the murder of an elderly woman in County Wicklow. Not 'only had the woman been murdered', the Irish Independent observed, she also had been 'outraged'. ${ }^{33}$ Such episodes may call for a reappraisal of the supposition that murder cases with a sexual element were rare. ${ }^{34}$

The last man to be executed was Michael Manning - another lethal rapist - who also had the dubious distinction of being the first (and only) person to be judicially executed in the Republic of Ireland, which had come into existence in 1949, marking the end of the Free State. ${ }^{35}$ Manning was convicted of the murder and attempted rape of Catherine Cooper, a sixty-eight-year-old nurse. After 'drinks in several licensed premises', Manning ambushed Nurse Cooper on the roadside outside Limerick City and suffocated her by stuffing grass into her mouth. The medical evidence revealed that she was found naked from the waist down; her face was distorted and swollen; three ribs were fractured and five teeth were missing. ${ }^{36}$ Manning was tried before Mr Justice Murnaghan at the Central Criminal Court. While there was no dispute as to the circumstances of the killing, the defence argued that the crime was one of manslaughter rather than murder and that the accused was insane. The judge dismissed the insanity plea, stating that he never known a case in which insanity was an issue "where medical evidence was not produced'. ${ }^{37}$ Murnaghan also dismissed the defence's point that at the time of the offence the accused's mind was so clouded by drink that he was incapable of knowing what he was doing' ${ }^{38}$ Manning was convicted of murder and, at 8 a.m. on 20 April 1954, he was hanged by Albert Pierrepoint in Mountjoy Prison.

When considering the aggregate picture, three aspects of Irish executions during the period under examination are noteworthy. These are the trend over time, the differential treatment of women, and the speed at which the apparatus of the state moved.

\section{Trend over time}

During the 1920s there was at least one hanging each year (fifteen in total took place between 1923 and 1929; with another twenty individuals receiving a death sentence that was later commuted to penal servitude). The trend in the 1930s was downward, with four executions between 1930 and 1938 (and eleven commutations). This mirrored a fall in the overall level of lethal violence. ${ }^{39}$ However, during the Second World War (known in Ireland as the 'Emergency') - despite a continuation of the downward trend in the murder rate - the number of executions surged and, indeed,

\footnotetext{
${ }^{33}$ Irish Independent, 1 Dec. 1927, 9.

${ }^{34}$ D. Ferriter, Occasions of Sin: Sex and Society in Modern Ireland, London, 2009, 118.

${ }^{35}$ The Republic of Ireland Act, 1948 came into force in 1949.

${ }^{36}$ Irish Independent, 2 Jan. 1954, 9. See also D. Walsh, Beneath Cannock's Clock, Cork, 2009.

${ }^{37} 89$ ILTR, 155.

${ }^{38}$ Memorandum for Government, 27 Feb. 1954, NAI, DT S15641.

${ }^{39}$ I. O'Donnell, 'Lethal Violence in Ireland, 1841 to 2003: Famine, Celibacy and Parental Pacification', 45 British Journal of Criminology (2005), 671-695.
} 
the balance of deaths to reprieves flipped, with more condemned persons being killed than spared: between 1939 and 1945 there were thirteen executions and nine commutations. Just two executions were carried out thereafter in the 1940s one each in 1947 and 1948 - and six years then elapsed before Michael Manning was hanged.

The reversal of the trend during the Emergency is not fully explained by the use of capital punishment to deal with the threat to the state posed by the IRA. Indeed, most of those executed during this period (seven out of thirteen) were ordinary citizens whose displays of interpersonal violence had no wider ramifications. It could be argued that the severity of the response to the IRA contributed to callousness insofar as other killers were concerned. This is seen in the number of executions rising at a time of declining homicide and in the changing balance between deaths and reprieves; what we might describe as the 'mercy ratio'. This was a temporary phenomenon. After the Emergency the use of the gallows resumed its downward spiral and the mercy ratio switched back in favour of the condemned person. ${ }^{40}$ (A similar pattern is seen in the immediate aftermath of the civil war - a dozen people, including the only woman ever executed in Independent Ireland, were hanged between 1923 and 1926. Such a concentration of executions was exceptional and it is reasonable to suppose that the preparedness to resort to the death penalty during the civil war led to a hardening of attitude that took some years to soften.)

\section{Gender}

The gender difference in commutation is striking. Between 1923 and $1964,{ }^{41}$ men who were sentenced to death were just as likely to die as to be reprieved (thirtyfour fell into each category). ${ }^{42}$ But for women the situation was radically different.

In October 1924 Annie Walsh, together with her nephew Michael Talbot, murdered her husband, Edward Walsh. At the trial, Walsh accused Talbot of shooting her husband. This was at odds with Talbot's testimony that Annie had killed Edward with a hatchet while he held down the victim's hands. It also conflicted with the medical officer's statement that there was no evidence of shooting and that the injuries were consistent with hatchet blows. Talbot's insanity plea proved futile and he was hanged on the same day as his aunt. They were executed separately - Talbot at 8 a.m., Walsh at 8.45 a.m. - by Thomas Pierrepoint and an assistant identified as 'Robinson'. ${ }^{43}$ The Irish Independent reported that Walsh had been hoping for a reprieve until the end and that: 'She showed signs of nervous emotion when the last moments arrived and, it is stated, walked falteringly to the scaffold, all the time in prayer'. ${ }^{4}$

\footnotetext{
${ }^{40}$ Fifteen persons sentenced to death were reprieved between 1946 and 1964. In another four cases a death penalty was overturned by the Court of Criminal Appeal and not re-imposed after a retrial.

${ }^{41}$ Section 1 of the Criminal Justice Act 1964 restricted the use of the death penalty.

${ }^{42}$ Eight death sentences were overturned by the Court of Criminal Appeal between 1924 and 1964 . These cases are omitted from our analysis.

${ }^{43}$ Irish Independent, 6 Aug. 1925, 8.

${ }^{44}$ Ibid.
} 
Another twenty-one women were sentenced to death but reprieved. ${ }^{45}$ Sometimes this was an attempt by the government to temper the ferocity of the law with mercy for the distressed mother who destroyed her infant child. Prior to the introduction of the Infanticide Act, 1949 any murder of a child carried the death penalty: twelve such mothers were spared. However, the remaining cases involved murders as heinous as those carried out by men. Leaving aside the cases of baby-killing the gender difference in execution remains pronounced: half of male murderers died compared with one in ten females.

For women whose death sentences were commuted the time served before release averaged three and a half years, ${ }^{46}$ but there was wide variation. Deborah Sullivan was released a little more than four months after her conviction for the murder of her illegitimate child in Co. Kerry. An unmarried woman aged twenty-one she set out for the County Home for her confinement on St. Valentine's Day in 1929. On the way she gave birth to a male child on the mountainside. The medical evidence demonstrated that the child had been born alive, but its dead body was found in a stream. The defence argued that after the birth Sullivan felt weak and frightened and put the baby in a bush; she was unable to explain the drowning. The jury struggled to arrive at a verdict and informed the judge that their difficulty related to the young woman's state of mind. Mr Justice O'Byrne explained that it was up to the defence to establish that Sullivan was unable to appreciate her actions and they had not done so. Accordingly, on 13 June 1929 the jury returned a verdict of guilty with a 'strong recommendation to mercy having regard to the exceptional circumstances under which the act was committed'. ${ }^{47}$ The judge advocated that early effect be given to the recommendation of the jury:

the act was committed immediately after birth when the accused must have still been suffering from the pangs and subsequent prostration of child-birth. She was living at home at the time and she stated in her evidence that she was terrified of her mother. May I suggest that this is a case in which the mental condition of the accused, who is quite a young girl, may be seriously prejudiced by her remaining for any considerable time under sentence of death. $^{48}$

The government accepted these recommendations and Sullivan was released on 2 November $1929 .^{49}$

At the other end of the spectrum Hannah Flynn served eighteen years and eight months before she was discharged. Flynn, a twenty-eight-year-old domestic servant, was sentenced to death by Mr Justice Pim at the Dublin Commission on 27 February 1924 for murdering the wife of a Kerry farmer, 'her head being

\footnotetext{
${ }^{45}$ The final female murderer whose death sentence was commuted to life imprisonment was Mary (Mamie) Cadden, the infamous Dublin abortionist, who was convicted in November 1956.

${ }^{46}$ This is the median value. It is used in preference to the mean which is distorted by a small number of extreme values. The mean was five years and one month.

${ }^{47}$ Return of persons sentenced to death from 1st April 1922 to 17th June 1937, NAI, DT S7788A.

${ }^{48}$ Death Sentence - Deborah Sullivan, 17 June 1929, NAI, DT S5886.

${ }^{49}$ Death sentences and commutations ledger, Mountjoy Prison Museum.
} 
hacked with a hatchet'. ${ }^{50}$ Despite the shocking wounds on the woman, the jury entered a strong recommendation for mercy 'on account of low mentality of prisoner'. 51 The judge also recommended a reprieve, stating that 'the prisoner was of low mentality and that her responsibility was much below normal'. ${ }^{2}$ Flynn's sentence was subsequently commuted but she was not released until 23 October 1942. By this juncture she was 'not considered quite normal' and a Department of Justice memorandum revealed that she had been 'kept in prison for such a long period' because no person could be found to look after her on release. The Good Shepherd Sisters agreed to take Flynn into their care as they had done several weeks earlier for another female lifer, Hannah O'Leary, who had served almost as long (seventeen years and three months). ${ }^{53}$

Men whose sentences were commuted served more than twice as long as women - seven and a half years on average - but the range was narrower (one year and nine months to twelve years). ${ }^{54}$

\section{The pace of justice}

The time intervals between crime and conviction, and between conviction and execution, repay scrutiny on account of their brevity and the almost unseemly haste with which politically-motivated offenders were put to death. For the twenty-nine non-political offenders, the average time between the commission of the offence and the sentence of the court was a little over four months. ${ }^{55}$ There was a wide range here, from ten days for William Downes to more than two years for James Myles. Things happened quickly after sentencing, with executions taking place around one month later. ${ }^{56}$ Into this brief period of time were compressed petitions on behalf of the condemned person; the appeals process; cabinet review of the sentence, any judicial observations and the jury's recommendation (if any); confirmation of the execution and the practical arrangements for securing the services of an English hangman.

Turning our attention to the six IRA men, it can be seen that matters progressed with even greater rapidity. Typically, conviction followed crime within a fortnight ${ }^{57}$ and within another fortnight the condemned man had met his end. ${ }^{58}$ As these cases had been dealt with by non-jury courts with a limited right of

\footnotetext{
${ }^{50}$ Irish Independent, 4 April 1923, 5.

${ }^{51}$ Return of persons, NAI, DT S7788A.

${ }^{52}$ Ibid.

${ }^{53}$ Convicts serving life sentences (... having been originally sentenced to death) from 1888 to 1944 - with dates of release, NAI, DT S7788A.

${ }^{54} \mathrm{As}$ the spread of times served was narrower, the mean value for men (seven years and two months) was close to the median. These calculations are based on twenty-eight of the thirty-four reprieved men for whom data about time served could be obtained. See Names of persons who were sentenced to death since 1925 and whose sentences were commuted to life imprisonment, undated, Mountjoy Prison Museum.

${ }^{55}$ The median was 138 days; the mean was 226 days.

${ }^{56}$ The median time interval was thirty-four days; the range was twenty-one days (William Downes) to 117 days (Bernard Kirwan). The mean was 40 days. Kirwan's case was the first where an appeal on a capital charge was taken from the Court of Criminal Appeal to the Supreme Court. See Irish Times, 2 June 1943, 1, and [1943] IR 279.

${ }^{57}$ The median interval between crime and conviction was thirteen days (range: 4 to 761 ; mean: 218 ).

${ }^{58}$ The median interval between sentencing and execution was twelve days (range: 7 to 53; mean: 18).
} 
appeal $^{59}$ in a context where the government was resolute and the execution was carried out by local soldiers, there were few potential obstacles to overcome. There was considerable variation in the time to death within this sub-category of executed persons. Patrick McGrath, Thomas Green (alias Francis Harte, sometimes referred to as Tom Harte), Richard Goss and Maurice O'Neill were dead three weeks after the actions that led to their apprehension. In George Plant's case there was almost a year and a half between the act (the murder of alleged informer Michael Devereux in September 1940) and his conviction in February 1942, but seven days later he stood before a firing party in Portlaoise Prison. ${ }^{60}$ It appears that he 'bore his sentence philosophically'. 'He was a particularly nice fellow and seemed to have no fear', Sean MacBride recalled. 'The night before his execution he sat up reading, completely composed all night, and went to his death wearing his best suit'. ${ }^{61}$ All five men had in common their appearance before the Military Court. The wheels of justice ground more slowly for Charles Kerins, with more than two years elapsing between crime and conviction and another fifty-three days between conviction and sentence. He was prosecuted in the Special Criminal Court and executed like a common criminal, by hanging rather than by shooting.

Having set out what we have learned about those who were hanged or shot, we turn our attention next to those who carried out the hanging and shooting.

\section{EXECUTIONERS}

In 1956, a government memorandum espoused the view that capital punishment was 'un-Irish' and 'a relic of barbarism'. Worse still, the author averred, 'The humiliating position in which we find ourselves is highlighted by the fact that we have to import an English hangman to carry out our executions'. ${ }^{62}$ A motley succession of professionally-trained executioners had been employed in Ireland since the 1870s - Marwood, Berry, Scott, Binns, the Billingtons, Ellis, and the Pierrepoints English specialists reviled by the Irish public. ${ }^{63}$ Post-Independence, responsibility for conducting hangings in Ireland remained, for want of a better word, 'colonised'. ${ }^{4}$

The first execution by hanging in the Free State provoked much conjecture, but the 'identity of the executioner was not disclosed'. 65 The extant archival evidence,

\footnotetext{
${ }^{59}$ Appeals were permitted from the Special Criminal Court but no such right existed for those convicted by the Military Court.

${ }^{60}$ See M. Moroney, George Plant and the Rule of Law: The Devereux Affair 1940-42, Tipperary, 1989, and Department of Justice, Memorandum, 7 Nov. 1945, NAI, DT S12741.

${ }^{61}$ See Coogan, IRA, 158. Ironically, on 30 June 1940 Plant had applied (unsuccessfully) for a commission in the Defence Forces, suggesting that his background in the IRA rendered him 'reasonably useful in charge of green troops who will not give their best under orthodox military discipline'. Letter from George Plant to Frank Aiken, 3 June 1940, Military Archives, Cathal Brugha Barracks, G2/3292.

${ }^{62}$ Department of Justice, Memorandum for Government, 12 April 1956, NAI, DT S7788B.

${ }^{63}$ For material relating to British hangmen in pre-Independence Ireland see B.J. Bailey, Hangmen of England, London, 1989; H. Bleakley, The Hangmen of England, London, 1929; S. Fielding, The Executioner's Bible, London, 2008; Vaughan, Murder Trials in Ireland.

${ }^{64}$ For an overview of executioners and executions in an English context, see S. McLaughlin, Execution Suite: A History of the Gallows at Wandsworth Prison 1878-1993, London, 2004; and S. McLaughlin, Britain's Last Executioner: The Life of Harry B. Allen, London, 2007.

${ }^{65}$ Irish Times, 30 Nov. 1923, 7.
} 
however, suggests continuity rather than change. Thomas Pierrepoint, who had officiated at the final political hangings during the War of Independence, was appointed for the execution of William Downes in 1923 after apparently negotiating a 'separate private contract' with the Irish authorities. ${ }^{66}$ Thus, in one of the most aberrant of dynasties, Thomas Pierrepoint, his brother Henry, and his successor, Henry's son Albert, were paid to execute Irish prisoners over a period comprising precisely half a century. Henry's last official engagement in Ireland was the hanging of Joseph Heffernan in Kilmainham Gaol in 1910, the same year his name was removed from the Home Office list of approved executioners. Albert later maintained the removal was 'not through any professional failure on my father's part', but the records tell a different story. As one dismayed Chief Warder wrote:

I beg to report for your information that the Executioner Pierrepoint arrived at this prison at 3-45 p.m.; he was considerably the worse for drink. I gave him what information he required respecting the condemned prisoner. The Assistant Executioner Ellis (who was at the gate awaiting his arrival, having reported himself some 30 minutes before) took down the particulars he asked for and Pierrepoint then opened a volley of abuse calling him a dirty Irish B- and made to strike him. He was prevented but he still continued his abuse. ${ }^{67}$

Assistant Executioner Ellis wrote a letter of complaint in a similar vein to the Home Office which culminated in Henry's dismissal. ${ }^{68}$ It was due to such animosities that Thomas Pierrepoint never engaged any member of the official Home Office list of approved executioners as his assistant when administering death sentences in Dublin. He was, according to his nephew Albert, determined to keep the 'jealousy and in-fighting' that occurred in Britain off the 'Irish scene' and, to this end, endeavoured to keep these operations within the family. ${ }^{69}$

Whether or not such reminiscences are entirely accurate, there is little doubt that Thomas Pierrepoint had supplanted John Ellis as the principal 'operator' in Mountjoy Prison by June $1921 .^{70}$ Ellis, a barber from Rochdale, had acquired infamy in Ireland due to his involvement in a number of high profile Republican cases. He had been responsible for the execution of Roger Casement in London's Pentonville Prison in August 1916, a job he reputedly went to do 'as pleased as a school boy'. ${ }^{71} \mathrm{He}$ also officiated at the hanging of eighteen-year-old Kevin Barry in Mountjoy Prison in November 1920 and the execution of six Republican prisoners in March 1921. He later evoked this traumatic morning: 'I once hanged six people before breakfast ... They were Sinn Feiners. That was a terrible day, and the strain was dreadful'. ${ }^{72}$

\footnotetext{
${ }^{66}$ A. Pierrepoint, Executioner Pierrepoint: An Autobiography, London, 2005, 101.

${ }^{67}$ Letter from W.C. Hale to Governor of Chelmsford Prison, 13 July 1910, National Archives United Kingdom (NAUK), HO144/22510.

${ }^{68}$ S. Fielding, Pierrepoint: A Family of Executioners, London, 2008, 96-98.

${ }^{69}$ Pierrepoint, Executioner, 102.

${ }^{70}$ Executioners were sometimes euphemistically described as 'operators' in official correspondence. See, for example, letter from Department of Justice to J.A. Belton, 1 Aug. 1940, NAI, DFA 202/950.

${ }^{71}$ Daily Mail, 22 Sept. 1932, NAUK, HO 144/22510.

${ }^{72}$ Daily Express, 21 Sept. 1932, NAUK, HO 144/22510.
} 
In such circumstances, it is hardly surprising that the IRA threatened to assassinate Ellis, a threat that was taken seriously by the British authorities. Erney Blackwell of the Home Office wrote 'it may be rather a delicate matter affording protection to Ellis. He is a good man at his job and doesn't funk'. It would be 'very awkward', he continued, 'if anything happened to him, as in all probability it would make it difficult to find another man who would readily take his place in this particular kind of case where some danger is incurred in carrying out the duty'. ${ }^{73}$ Ellis may still have been deemed the model candidate for executing Irish Republicans in England, but it appears that Ellis's relationship with Mountjoy Prison came to an abrupt end in 1921 after he was apparently short-changed by the Irish authorities in the aftermath of executing Thomas Traynor. In May 1921, he expressed his disgruntlement in a letter to Dublin Castle:

I shall be pleased if you will kindly reconsider the fee of $£ 10$ which you decided I must have for carrying out the execution of Thomas Trayner [sic] at Mountjoy Prison on April 25th, as you are aware you have allowed me $£ 15$ for single executions of Sinn Feiners. I am sure you will agree it is little enough. The risk I have, the inconvenience I am put to, also the jeers and insulting remarks I have to put up with. ${ }^{74}$

Whether this dispute was resolved is uncertain, but it is manifest that Ellis did not officiate again in Ireland. ${ }^{75}$

The inferior rate of pay coupled with the inherent danger did not dissuade Thomas Pierrepoint. In 1931, he informed the Governor of Mountjoy Prison that he 'shall be very pleased to officiate ... on the same terms as before $£ 10$. and also travelling expenses for my self and £3.3.0 for my assistant and also travelling expenses' ${ }^{76}$ When executioners travelled to Ireland they exercised due caution. As Thomas himself put it when describing his journeys on the boat: 'I shall be coming via Holyhead and Kingstown and I will make my way straight to the Prison Sir, as it does not do to hang about and advertise yourself on these jobs'. ${ }^{77}$ By 1940, the 'usual' arrangements became 'air passage by the afternoon service from Speke Airport [Liverpool] to Dublin Airport'. 78

The fraught nature of travelling to Mountjoy was also recalled by Albert Pierrepoint in his autobiography, Executioner, where he asserted that it was 'only on his trips to Ireland' that his uncle was 'armed' 79 'Executioners', he reminisced, were 'not popular characters either in the North or in the Free State' but in the latter jurisdiction the 'risk of mobbing was much greater since the Free State was known never to use Irishmen but only to employ British

\footnotetext{
${ }^{73}$ Letter from E. Blackwell to Horwood, 26 July 1922, NAUK, MEPO 38/157.

${ }^{74}$ Letter from John Ellis to Prison Commission, NAUK, HO 351/135; See also O'Brien, 'Capital Punishment', 224.

${ }^{75} \mathrm{He}$ retired in 1923 and committed suicide by cutting his throat in 1932.

${ }^{76}$ Letter from Thomas Pierrepoint to Governor of Mountjoy Prison, 23 July 1931, Mountjoy Prison Museum.

${ }^{77}$ Letter from Thomas Pierrepoint to Governor of Mountjoy Prison, 20 Nov. 1923, NAI, DJUS 2007/56/1.

${ }^{78}$ Letter from J.A. Belton to Department of External Affairs, 22 Nov. 1944, NAI, DFA 202/950.

${ }^{79}$ Pierrepoint, Executioner, 104.
} 
executioners' ${ }^{80}$ Albert - not always the most reliable source - also stated that the Irish police 'encouraged it', but Thomas makes no reference to being 'armed' in a letter to the governor of Mountjoy where he stresses the importance of travelling light to remain incognito:

I expect they [other passengers on the boat] thought of seeing me with a lot of luggage but I never carry any with me only in my pocket a pair of pliers a two foot rule and tape measure as I think it better than carrying a hand bag I think it gives the game away I believe in going nice and quiet about my business and not let every body know who I am. ${ }^{81}$

The unruly reception that a hangman could receive was exemplified at the hanging of Patrick McDermott in 1932, Albert's first execution experience, when a number of youths unfurled a banner proclaiming: 'Pierrepoint the British hangman hangs Irishman. Is this justice? ${ }^{82}$ Yet whatever the reaction outside Mountjoy Prison, these sentiments were not replicated within its walls. 'There is very little trouble with Irish prisoners', Thomas observed. 'I admire their fortitude and resignation, and, I may add, their spirituality' ${ }^{83}$ Albert also paid Irish prisoners a macabre accolade before the execution of Michael Manning when he commented that: 'I love hanging Irishmen - they always go quietly and without trouble. They're Christian men and they believe they're going to a better place'. ${ }^{84}$

But it was not just Irish prisoners who merited acclaim. It was also to 'the credit of Irishmen that none of them would act as public hangman'. ${ }^{85}$ 'No decent man', one concerned citizen declared, 'would, on any account, do the hangman's work. The hangman's is probably the only State service which a loyal citizen would feel justified in refusing to perform. ${ }^{86}$ That Irish executioners were non-existent was touted as irrefutable evidence that capital punishment was 'naturally abhorrent to the Irish people' and 'alien to our way of thinking ${ }^{87}$ Yet a much concealed footnote in the history of capital punishment in Ireland is the government's clandestine endeavour to train and employ a local executioner in the $1940 \mathrm{~s} .{ }^{88}$ It was understandably, as Tim Carey noted, a delicate and a furtive matter, but two letters remain in existence that cast some light on this episode. The first dates from 1941 and appears to encompass arrangements for a prospective hangman to travel to Dublin for an 'interview'. The correspondence also describes how the author could be identified on arrival:

\footnotetext{
${ }^{80}$ Ibid.

${ }^{81}$ Letter from Thomas Pierrepoint to Governor of Mountjoy Prison, 3 Dec. 1923, NAI, DJUS 2007/56/1.

${ }^{82}$ Pierrepoint, Executioner, 111.

${ }^{83}$ Irish Independent, 26 April 1929, 6.

${ }^{84}$ Irish Post, 26 July 2006.

${ }^{85}$ Irish Times, 25 Oct. 1948, cited in O'Brien, 'Capital Punishment', 241; See also Seanad Debates, vol.46, cols.184-92 (30 May 1956).

${ }^{86}$ Letter from Henry R. Chillingworth to Douglas Hyde, 15 Nov. 1938, NAI, PRES 1124.

${ }^{87}$ Department of Justice, Memorandum for Government, 12 April 1956, NAI, DT S7788B.

${ }^{88}$ On one occasion a Londoner of Irish parentage volunteered his services as a hangman. He felt that he would be suitable for the job given that he had 'attended numerous executions' while stationed at Crete with the Royal Navy. Letter from T. Delury to Secretary, High Commissioner, Irish Free State, 26 Nov. 1932, NAI, DFA 44/30.
} 
Age: 46. Height 5'7'. Med. to stout build, erect bearing. Clean shaven, fresh complexion, Blue eyes. Small straight nose. Good teeth, fair hair, turning grey. Bald in temple with a slight growth of hair on top of head. I shall be wearing Blue suit with grey hair stripe. Black shoes. Blue velour hat. If dry I shall carry on my left arm fawn colour shower proof coat, if wet I shall be wearing that coat. On arrival at Kingsbridge I shall go towards the Engine, and remove my hat and rub my forehead for a moment. ${ }^{89}$

The decision to employ this stout middle-aged man as the official Irish hangman appears to have been taken soon thereafter, but plans were only belatedly made for his training in Strangeways Prison in Manchester in February 1945. ${ }^{90}$ For this trip he was issued with travel documents bearing the pseudonym 'Thomas Johnston'. 91 It was not unusual for executioners to adopt pseudonyms when travelling on "professional engagements'. A letter in the files of the Department of External Affairs refers, for instance, to the 'usual requests for exit permits' from Thomas and Albert Pierrepoint, who will travel 'under the names of Thomas Clarke and Albert Clough'. ${ }^{92}$

It was at Strangeways that Albert Pierrepoint first met his Irish apprentice, but it seems that he has misgivings from the outset, remembering 'Johnstone' as 'old and short and timid' and recalling that when he 'first took him into the execution chamber his face went as white as chalk'. ${ }^{93}$ After two nights' basic training Johnston returned to Dublin. When contacted in relation to the execution of Daniel Duff, scheduled for December 1946, he wrote to the Governor of Mountjoy, Sean Kavanagh, stating that:

I am prepared to officiate should it take place, but about acting alone, I think that I explained to you about a year ago, that I should like to assist at say one more, as you are already aware the only practical experience I've got is of attending one, and that was about 1 year and 9 months ago ... as you know this is not something one sees every day and while I am sure I could carry it out at the same time I am not perfectly sure of myself, and it would never do for anything to go wrong. The first time I was speaking to you before leaving Dublin you assured me that our friend would come over for one or two more. ${ }^{94}$

Duff, formerly a member of An Garda Síochána [national police force], had been sentenced to death for the murder of a fellow Garda, but he was subsequently reprieved. It appears, from Pierrepoint's execution diary at least, that an 'S. Johnston' was present at the execution of Joseph McManus in $1947 .{ }^{95}$ According to Pierrepoint, it was initially agreed that 'Johnstone' would 'undertake the execution' while he 'acted as

\footnotetext{
${ }^{89}$ T. Carey, Mountjoy: The Story of a Prison, Cork, 2000, 210-211.

${ }^{90}$ This was the month before James Lehman was hanged. The Mountjoy Prison Registry of Deaths indicates that Johnston received a fee of $£ 20$ for his part in Lehman's execution.

${ }^{91}$ Ibid.

${ }^{92}$ Letter from J.A. Belton to Department of External Affairs, 22 Nov. 1944, NAI, DFA 202/950.

${ }^{93}$ Pierrepoint, Executioner, 161.

${ }^{94}$ Carey, Mountjoy, 210-211.

${ }^{95}$ The surname is variously spelled 'Johnston', 'Johnson' and 'Johnstone'.
} 
assistant'. This arrangement, as Pierrepoint later recollected, did not proceed as anticipated:

I stood back and waited for Johnstone to get things going with my assistance, but he had forgotten all his training and did not really have a clue ... we went back to the execution chamber for the last preliminaries, but again Johnstone had forgotten his part and I had to keep stepping in to help him ... The Governor saw that I was not too happy, and he walked away to talk with one of the officers. He came back and said: "Mr Pierrepoint, I think you should take charge." I said "That's up to you, sir." The Governor looked across to see how Johnstone was reacting, and my own interpretation of his attitude was that he was very pleased. ${ }^{96}$

In the end, the hanging of McManus 'was carried out to everybody's satisfaction'97 and the career of the would-be Irish hangman came to an unconsummated conclusion.

We can learn something of what a 'satisfactory' hanging entailed by considering the modus operandi of an Irish execution. The proceedings typically began with mass being celebrated in the condemned person's cell. Shortly before 8 a.m. the executioner would enter and apply the pinion apparatus. 'A broad leather body belt is clasped round the victim's waist, and to this the arm straps are fastened', wrote former convict Walter Mahon Smith. ${ }^{98}$ 'Two straps an inch and a half wide, with strong steel buckles, clasp the elbows and fasten them to the body belt, while another strap of the same strength goes around the wrists and is fastened into the body belt in front'. 99 Pinioning the arms reduced the prisoner's ability to struggle on the short walk to the gallows, a mere fifteen paces in Mountjoy, according to one newspaper account. ${ }^{100}$ On reaching the final destination, the executioner stood the prisoner on the trap doors directly beneath a beam from which dangled a threequarter inch Italian hemp rope; the Pierrepoints took the precaution of marking this spot with chalk. Before the noose was tightened, the legs were strapped and a white linen cap was placed over the prisoner's head. The trap doors were then opened and the prisoner dropped. If the preparations had been sufficiently thorough, the neck was broken (usually around the third cervical vertebra) and death was almost instantaneous. Otherwise strangulation ensued with the prisoner remaining suspended until the life was choked out of him.

When it comes to death by shooting, less is known. In the cases of McGrath and Green, the Provost Marshal, Michael McHugh, was instructed to 'carry into execution the said Order and Sentence of the Court at 06.30 hours on the 6th day of September, 1940, at Mountjoy Prison in the presence of Commandant Michael Lennon, a Medical

\footnotetext{
${ }^{96}$ Pierrepoint, Executioner, 162-163.

${ }^{97}$ Ibid., 163.

${ }^{98}$ D83222, I Did Penal Servitude, Dublin, 1946, 100.

${ }^{99}$ Ibid., 100-101. It appears that Mahon-Smith's description of the execution equipment was outdated and that wrist straps were used instead of a body belt, the latter device having fallen into desuetude with the regular employment of assistant executioners (Stewart McLaughlin, personal communication, 3 May 2011).

${ }^{100}$ Irish Independent, 26 April 1929, 6.
} 
Officer and a Chaplain'. ${ }^{101}$ It was also directed that the 'Officer Commanding, Eastern Command' would 'supply a firing party under the Command of an Officer'. ${ }^{102}$ The numerical composition of the firing party is not recorded but its configuration may have been based on international practices at the time, consisting of "not less than eight and not more than twelve enlisted men skilled in the use of the regulation rifle'. 103

A confidential Home Office document dating from 1941 may provide some further insights in this regard, stipulating that the "prisoner may be shot either standing up strapped to a post fixed in the ground if available, or sitting down strapped to a chair'. ${ }^{104}$ 'A minute or two before the hour fixed for the execution', the Deputy Assistant Provost Marshal (DAPM), was required to 'satisfy himself as to the identity of the prisoner, whose arms will then be pinioned to his sides with a strap' ${ }^{105}$ The medical officer would then 'slip a cap over the prisoner's head and fix an aiming mark over his heart'. ${ }^{106}$ The document also specified that the firing party was to report to the place of execution in sufficient time to enable the following procedure to take effect:

On arrival the firing party will be ordered to load with one live round. They will then ground arms and be marched a short distance away, so that they cannot see their arms, where it will be explained to them that all commands after the appearance of the prisoner will be by signal and in silence, except the command 'fire' and that the greatest service they can render the prisoner is to shoot straight at the mark. ${ }^{107}$

At this juncture the DAPM alters 'the place of the rifles' and reloads two of them with 'blank ammunition' in order to sustain the fiction that the members of the firing party would not know for certain who had fired the fatal shots. The firing party then take up position and the prisoner is produced, arms pinioned and face covered.

As soon as the prisoner has been secured the D.A.P.M. will signal to the firing party, who will come to the aiming position. On a further signal from the D.A.P.M. to the O.C. firing party the latter will give the command 'fire' ... If the Medical Officer indicates to the D.A.P.M. that the prisoner is not dead, it is his duty to administer the 'coup de grace' with his revolver. ${ }^{108}$

The firing party would subsequently 'ground arms and be marched away a short distance' while the DAPM again changes the position of the rifles and unloads them. When this is done they 'return, take up arms and march away to their unit'. ${ }^{109}$ The

\footnotetext{
${ }^{101}$ Letter from Liam O h-Aodha, Adjutant General, to Commandant Michael McHugh, 5 Sept. 1940, NAI, DT S12048-A.

${ }^{102}$ Ibid.

${ }^{103}$ United States War Department, Execution of Death Sentences, undated, NAUK, WO 322/0624.

${ }^{104}$ Procedures for military executions by shooting, 10 Sept. 1941, NAUK, WO 322/0624.

${ }^{105}$ Ibid.

${ }^{106}$ Ibid.

${ }^{107}$ Ibid.

${ }^{108}$ Ibid.

${ }^{109}$ Ibid.
} 
Irish army did not develop its own procedures for military executions, choosing instead to follow the British model which remained virtually unchanged in the new regulations adopted in $1956^{110}$ and revised in $1980 .^{111}$ The scant surviving evidence reveals that a court of enquiry was convened in the aftermath of each execution. The findings were predictable: death by shooting was invariably instantaneous and the certificate of the surgeon confirmed the cause of death as 'Gun Shot Wounds'. ${ }^{112}$

But the hangman or firing party were only required for the minority of convicted murderers whom the cabinet did not see fit to reprieve. We turn next to an exploration of the government's use of capital punishment, in particular as it related to politicallymotivated crimes which, while few in number, generated high levels of legal, political and public concern.

\section{POLITICAL PRESSURES AND THE EMERGENCY (1939-45)}

As noted above, one reason why there was continuing political support for capital punishment was its perceived efficacy as a deterrent to potential subversives, but at the same time the threat posed by such individuals was deemed to be such that extraordinary legal powers were required. The government's rationale for the Emergency Powers (Amendment) (No. 2) Act, 1940 stemmed from what were considered to be the imperfections of the Offences against the State Act, 1939 which had created the Special Criminal Court. ${ }^{113}$ The Department of Justice criticised the latter on the basis that it could not impose the death sentence for anything except murder or treason, whereas in certain circumstances the fear of the capital penalty may be the only adequate deterrent for such crimes as sabotage, shooting with intent to kill, etc. ${ }^{114}$ The Department also proposed that the hunger strike device, blatantly employed to delay trial, could 'be adequately met only by trying the accused in his absence or by a procedure so summary that the accused is tried before his health has suffered so much that he is not fit to stand trial'. ${ }^{115}$ During the debate on the bill, the Minister for Justice, Gerald Boland, informed members of the Seanad [upper house] that:

The government has decided to ask for these powers because they felt that they are absolutely necessary ... In an emergency like the present, people who go around with guns or fire at officers of State in the execution of their duty, or try to take the law into their own hands, or to upset the Government, will have to be dealt with in a summary and drastic fashion. ${ }^{116}$

The Military Court envisaged by the Act was established by the Emergency Powers (No.41) Order, 1940. Under the terms of the Order, this court was to be composed of

\footnotetext{
${ }^{110}$ The Execution of Sentences of Death (Army) Regulations, 1956.

${ }^{111}$ Ministry of Defence, March 1980, The Provost Manual, s.7.

${ }^{112}$ Certificate of the Surgeon, 6 Sept. 1940, NAI, DT S12048A (for executions of McGrath and Green).

${ }^{113}$ F.F. Davis, The History and Development of the Special Criminal Court, Dublin, 2007.

${ }^{114}$ S. Ó Longaigh, Emergency Law in Independent Ireland, 1922-1948, Dublin, 2006, 248.

${ }^{115}$ Ibid.

${ }^{116}$ Seanad Debates, vol.24, col.1900-02 (26 June 1940) cited in Ó Longaigh, Emergency Law, 249-250.
} 
'any three persons, being commissioned officers of the Defence Forces, who are for the time being members of any Special Criminal Court'. Prior to the commencement of a trial, the Military Court was to assure itself 'that a statement of the charge or charges against him has been delivered to such person and that he has been afforded any facilities (which he has requested and which such Military Court, having regard for the exigencies of the situation, considers reasonable) for preparing his defence, and if not so satisfied shall adjourn such trial for such time as such Military Court thinks proper'. The court was to determine its own procedures, and every question arising before it was to be decided by majority vote. Where the Military Court found a person guilty of an offence specified in the schedule to the $\operatorname{Order}^{117}$ it was required to sentence them to 'suffer death by shooting'; this was the sole available sanction. ${ }^{118}$ The legislation stipulated that 'no appeal shall lie in respect of such conviction or sentence'. ${ }^{119}$ The 'normal method of executing the death sentence, viz, with the interval of several weeks after judgement - longer in cases of appeal - and then by a process (hanging) which requires the attendance of a skilled executioner, whose attendance might be prevented by accident or design' was deemed unsuitable by the Department of Justice for 'cases in which the speed and certainty of punishment' were 'essential considerations'. 120

A death sentence handed down by the Military Court did not always result in an execution. It merely transferred the case from three "commissioned officers of the Defence Forces' to the government, and replaced the question of culpability with the question of clemency. ${ }^{121}$ Indeed, there appeared to be no anticipation that all of the convicted persons would be executed. The list of scheduled offences had been accepted by the government on the basis that there would be an opportunity in every case to substitute penal servitude for death. ${ }^{122}$ As matters transpired almost half of those sentenced to death under the Order had their sentences commuted (see Table 2). ${ }^{123}$ This would suggest that the cabinet was making its decisions on an individualised basis; having created a context where a court could return a swift and terminal decision it reserved the right not to follow through. ${ }^{124}$

As with civilian cases, clemency was completely at the discretion of the government, which could grant or deny a reprieve for whatever reasons it deemed apposite. In this regard, a Republican 'lineage' could be advantageous. ${ }^{125}$ On 13 June 1940, prior to the establishment of the Military Court, Thomas MacCurtain, son of the

\footnotetext{
${ }^{117}$ Numerous offences were listed in the schedule including: treason; possession of documents prejudicial to public safety or the integrity the state; damage to equipment belonging to the Defence Forces; murder; resisting arrest; unlawful imprisonment; causing explosions; possessing explosive substances, firearms or ammunition; and attempting or conspiring to commit any of the foregoing.

${ }^{118}$ Emergency Powers (No.41) Order, 1940, Statutory Rules and Orders, 1940, no.237.

${ }^{119}$ Emergency Powers (Amendment) (No.2) Act, 1940, s.3.

${ }^{120}$ Ó Longaigh, Emergency Law, 249.

${ }^{121}$ Emergency Powers (No.41) Order, 1940, s.10.

${ }^{122}$ Ó Longaigh, Emergency Law, 252.

${ }^{123}$ Trials by Military Courts under Emergency Powers (No.41) Order, 1940, 16 Aug. 1940, NAI, DT S11908.

${ }^{124}$ If IRA men were not executed quickly they tended to be released quickly, emphasising that the threat they posed was very context-dependent.

${ }^{125}$ O'Halpin, Defending Ireland, 248.
} 
TABLE 2

MILITARY COURTS AND CABINET DECISIONS

\begin{tabular}{lll}
\hline Prisoner & \multicolumn{1}{c}{ Trial Date } & \multicolumn{1}{c}{ Disposal } \\
\hline Patrick McGrath & 20 Aug. 1940 & Executed \\
Thomas Green & 20 Aug. 1940 & Executed \\
Thomas Hunt & 23 Sept. 1940 & Transferred to Curragh Internment Camp \\
Richard Goss & 1 Aug. 1941 & Executed \\
John McCaughey & 18 Aug. 1941 & Died on Hunger Strike in 1946 \\
George Plant & 2 March 1942 & Executed \\
Patrick Davern & 5 March 1942 & Served three years \\
Michael Walsh & 5 March 1942 & Served three years \\
Maurice O'Neill & 5 Nov. 1942 & Executed \\
\hline
\end{tabular}

Sinn Fein Lord Mayor of Cork who had been assassinated in March 1920, was condemned to death by the Special Criminal Court for the murder of Garda John Roche in January of the same year. This sentence precipitated an outpouring of public emotion.

Reprieve petitions and letters to both the government and the President concerning civilian death sentences tended to come predominantly from local individuals and organisations, frequently at the instigation of the solicitor acting on behalf of the person awaiting death. ${ }^{126}$ Communications concerning condemned Republicans, however, transcended county and, on occasion, national borders, generating voluminous correspondence and petitions carrying hundreds and thousands of signatures. As the 'progeny of one of the martyrs of the Irish Revolution', ${ }^{127}$ MacCurtain evoked particular sympathy, deserving 'mercy for his father's sake', ${ }^{128}$ and 'for the sacrifices of the McCurtain [sic] family in the cause of Irish Independence'. ${ }^{129}$ 'I am sure you will appreciate the feelings of men like myself who through all the vicissitudes of political life have cherished memories of our fallen comrade', reasoned one correspondent, 'as we wait in anticipation of the evil hour when an English hangman is to be employed by an Irish government to choke the breath of life in our comrade's son. ${ }^{130}$ Another War of Independence veteran bemoaned the fact that 'Those of us who were associated, like yourself, with his father's national work hope that his memory will not be tarnished by the dreadful consummation that his son was hanged for murder'. ${ }^{131}$

So far as can be told from the surviving evidence, the cabinet was far from unanimous on MacCurtain's fate and some members probably feared the consequences of a decision that went against popular Republican sentiment. ${ }^{132}$ Due to die on 5 July 1940, MacCurtain was spared after some opportune litigation by his defence

\footnotetext{
${ }^{126}$ For the commutation of death sentences post-1937 see article 13.6 of Bunreacht Na hÉireann. See also Department of Taoiseach Memorandum, 29 Dec. 1938, NAI, DT S7788A.

${ }^{127}$ Ibid.

${ }^{128}$ Letter from unnamed correspondent to Mr. Crowley, 8 July 1940, NAI, DT S11974.

${ }^{129}$ Letter from Lorcán Ó Brádaigh to An Taoiseach, 6 July 1940, NAI, DT S11974.

${ }^{130}$ Letter from Patrick Brady to Eamon De Valera, 3 July 1940, NAI, DT S11974.

${ }^{131}$ Letter from Sean MacCárthaigh to Eamon De Valera, 3 July 1940, NAI, DT S11974.

${ }^{132}$ U. MacEoin, ed., Survivors, Dublin, 1980, 124.
} 
counsel, Sean MacBride. More in hope of deferment than success, MacBride sought a conditional order of habeas corpus, which Mr Justice Gavan Duffy dismissed the day before the scheduled execution. ${ }^{133}$ Shortly before the court offices closed, however, MacBride lodged an appeal to the Supreme Court. Endeavours were made to 'bring the Supreme Court together that evening', but as MacBride wryly remarked, 'they were unable because [Mr Justice] Murnaghan ... was out, diplomatically maybe, walking with his dog'. ${ }^{134}$ This forced a postponement of the execution and during the hiatus the government decided to allow MacCurtain to live. How close he came to death was captured by Maude Gonne (MacBride's mother) in a letter to De Valera on 8 July 1940:

Last week Mrs McCurtain [sic] said good bye to her son in Mountjoy. The English hangman had arrived to hang the son of the man the English had murdered. After she had said goodbye came the news that there was a week's delay in the execution, for the appeal against the refusal of an order of Habeas Corpus to be heard. ${ }^{135}$

But to claim that 'lineage' proved important for MacCurtain is not to suggest that clemency in political cases was merely a matter of connections with the 'Anglo-Irish Struggle'. ${ }^{136}$ A number of condemned prisoners with no direct link to 'the glorious years' were reprieved. ${ }^{137}$ Some with influential Republican support were executed.

When reprieve committees were established after Military Court convictions, arguments for clemency were not simply couched in terms of what one correspondent phrased as the 'technical legal aspect of the matter'. ${ }^{138}$ They also evoked memories of the civil war executions and alluded to the gallery of executed Republican martyrs. 'You have not yet found it necessary to enforce a political execution', one letter declared. 'Perhaps some of the group who were guilty of the '77' would rest satisfied if Fianna Fáil would be compelled to register even one'. ${ }^{139}$ Others appealed to De Valera on more personal grounds including his own experience of awaiting execution in the aftermath of the 1916 Rising. 'You yourself know what it is to wait all through a night waiting for the morning's death and the relief when news of the reprieve came'. ${ }^{140}$ The intention was clearly to put pressure on De Valera and his government by implying that a wrong decision would alienate large numbers of Republicans and 'create revulsion against government'. ${ }^{141}$ 'Realising the gravity of the present situation as it affects our country', a submission from a Fianna Fáil branch in Limerick

\footnotetext{
${ }^{133}$ [1941] IR 83.

${ }^{134}$ MacEoin, Survivors, 124.

${ }^{135}$ Letter from Maude Gonne to Eamon De Valera, 8 July 1940, NAI, DT S11974. Major John MacBride, father of Sean and husband to Maude Gonne, was executed in 1916 for his part in that year's Rising.

${ }^{136}$ Letter from Patrick Cashman to Eamon De Valera, 6 July 1940, NAI, DT S1 1974.

${ }^{137}$ Letter from Patrick Cashman to Eamon De Valera, 11 July 1940, NAI, DT S11974.

${ }^{138}$ Letter from Michael P. Boland to Eamon De Valera, 3 July 1940, NAI, DT S11974.

${ }^{139}$ Letter from Ted O’Sullivan to Eamon De Valera, 3 July 1940, NAI, DT S11974.

${ }^{140}$ Letter from G.S. Baker to Eamon De Valera, 4 July 1940, NAI, DT S11974.

${ }^{141}$ Telegram from John Quinn and Eamon Donnelly to Douglas Hyde, Aug. 1941, NAI, PRES/1/2030.
} 
declared, 'we believe the importation of a foreign hangman at the present time would shock the conscience of the Nation'. ${ }^{142}$

Timing would also prove to be a crucial factor. With little subversive activity in 1939, the government could 'appear to be magnanimous' towards the IRA, but by the summer of 1940 such leniency had come to an irrevocable end. ${ }^{143}$ Hunger strikes and shootings at members of An Garda Síochána coalesced with a wider deterioration in the security situation to ensure that the clemency belatedly afforded to MacCurtain would not be extended to others. On 7 May 1940, De Valera told the nation in no uncertain terms that:

Our policy of patience has failed and is over ... I warn those now planning new crimes against the nation that they will not be allowed to continue their policy of sabotage ... The law will be enforced against them. If the present law is not sufficient it will be strengthened; and in the last resort, if no other law will suffice, then the Government will invoke the ultimate law - the safety of the people. ${ }^{144}$

Despite this stark pronouncement, the summer of 1940 saw an escalation in the number of encounters between the Gardaí and the IRA in what has been described as a 'pattern of provocation, retaliation and revenge'. ${ }^{145}$ When a team of Garda detectives was searching a building in Dublin in August 1940, 'a burst of gun fire was directed at them from inside the shop portion of the premises'. ${ }^{146}$ Two Gardaí died as a consequence and Patrick McGrath, Thomas Green and Thomas Hunt fled the scene only to be fired on by the remaining detectives. One of the shots 'took effect' on Green, and when McGrath retreated to assist him, both men were overtaken and apprehended. Hunt managed to escape, only to be arrested five days later. ${ }^{147}$

McGrath and Green were tried four days after the killings. The prosecution submitted that there was a 'deliberate plan by these men to shoot their way to freedom at all hazards, to resist arrest by force, or to shoot first and then escape - to do it without warning, without notice and with a complete numbness in regard to the lives of the people who were in that shop behind the door'. ${ }^{148}$ Whether this was the case or not, the court only heard the prosecution's version. Both McGrath and Green 'declined to give evidence or call any witnesses or make any statement'. ${ }^{149}$ In the absence of a defence, the court unsurprisingly convicted the pair and sentenced them to 'death by shooting' after less than thirty minutes' deliberation. ${ }^{150}$

\footnotetext{
${ }^{142}$ Letter from An Rúnaidhe, Fianna Fáil Comhairle Ceanntar, to An Taoiseach, 2 July 1940, NAI, DT S11974.

${ }^{143}$ J. Bowyer Bell, The Secret Army: The IRA 1916-1919, Dublin, 1990, 171.

${ }^{144}$ M. Moynihan, ed., Speeches and Statements by Eamon De Valera 1917-73, Dublin, 1980, $433-434$.

${ }^{145}$ Bowyer Bell, Secret Army, 171.

${ }^{146}$ See Attorney-General v Thomas Green (alias Francis Harte) and Patrick McGrath, Statement of Offence, 16 Aug. 1940, NAI, DT, S12048A.

${ }^{147}$ Ibid.

${ }^{148}$ Irish Press, 21 Aug. 1940, 7.

${ }^{149}$ Attorney-General v Thomas Green (alias Francis Harte) and Patrick McGrath, Record of Proceedings, 20 Aug. 1940, NAI, DT S12048A.

${ }^{150}$ Attorney-General v Thomas Green (alias Francis Harte) and Patrick McGrath, Proceedings of Court of Inquiry, 6 Sept. 1940, NAI, DT S12048A.
} 
No sooner were McGrath and Green sentenced to death than a committee was instituted to lobby on their behalf and to collect signatures of support from across the country. Lobbyists adopted a similar approach to MacCurtain's supporters, focusing predominantly on McGrath's pedigree during the 'Irish revolution' rather than on the criminal culpability of the convicted men. 'It would [be] tragic', one petitioner articulated, "if Paddy McGrath being the first casualty at the hands of the British in the war of independence was sent to his doom by Irish soldiers.' ${ }^{151}$ 'It is unbelievable', wrote Josephine McGrath, 'that I should have to appeal for my brother's life to you, who was once his comrade-in-arms. ${ }^{152}$ Yet despite the historical connection and the support 'of men of probity and standing', the chances of clemency were extremely small. ${ }^{153}$ McGrath, 'prominent in the I.R.A.', may have been revered in petition circles as an 'unselfish highly patriotic Irishman' whose 'whole life \& strength' had been 'given to Ireland" 154 but by August 1940 he had become an unrelenting nuisance to the government. In 1939, for instance, McGrath had been charged under the Offences against the State Act but a nolle prosequi was subsequently entered 'owing to his inability to stand trial by reason of participation in a hunger strike'. ${ }^{155}$ During the time McGrath was awaiting trial in Mountjoy Prison on the aforementioned matter, there was an ill-fated attempt 'by some of the prisoners ... to effect an escape'. The endeavour 'failed because the amount of explosive employed was not sufficient to cause a breach in the outer wall of the prison', but there was little doubt that 'McGrath was one of the men responsible for this serious outrage' ${ }^{156}$

Thomas Green, by contrast, was a bit of an enigma. A less-experienced IRA campaigner than McGrath, Green was in his 'mid-twenties' at the time of the shootings and apparently belonged 'to the jurisdiction of the northern Government'. ${ }^{157}$ 'Nothing is known of this individual', one source observed, 'except that he was deported to Eire from England in February, 1940. ${ }^{158}$ 'He claimed to be a native of County Louth, but could not be identified as coming from that county.' 'Enquiries made in other areas', it concluded, also 'failed to yield any authentic information relative to his antecedents. ${ }^{159}$ Yet whatever chance youth or inexperience might save Green, it was apparent that McGrath had completely exhausted executive compassion. McGrath and the IRA 'had been treated, in the past, with a leniency probably unprecedented in history', but this had 'only encouraged

\footnotetext{
${ }^{151}$ Letter from John J. Sampson to Eamon De Valera, 21 Aug. 1940, NAI, DT S12048B. McGrath's ascribed status as 'the first casualty' in the War of Independence appears to be mere conjecture.

${ }^{152}$ Letter from Josephine McGrath to Eamon De Valera, 21 Aug. 1940, NAI, DT S12048B.

${ }^{153}$ Letter from T. Maguire to Eamon De Valera, 31 Aug. 1940, NAI, DT S12048B.

${ }^{154}$ Letter from Leo and Joey Hourigan to Miss Gleeson, 20 Aug. 1940, NAI, DT S12048B.

${ }^{155}$ Shooting at 98A, Rathgar Road, Resume of Case and Court Proceedings, 20 Aug. 1940, NAI, DT S12048A.

${ }^{156}$ Ibid.

${ }^{157}$ Letter from T. Maguire to Eamon De Valera, 31 Aug. 1940, NAI DT S12048B.

${ }^{158}$ Shooting at $98 \mathrm{~A}$, Rathgar Road.

${ }^{159}$ Ibid. Army files reveal a little more detail, giving his address as 'Castletown, Dundalk'. On a 'History Sheet' no information is noted other than that directly available to the observer, namely colour of hair (sandy), eyes (grey) and complexion (fresh). Green refused to disclose his home address, marital status, next of kin or occupation and his height and weight 'could not be taken' suggesting a less than cooperative prisoner. Military Archives, Cathal Brugha Barracks, G2/2723.
} 
them'. ${ }^{160}$ Recounting how his resolve had subsided in the face of McGrath's imminent death from the abovementioned hunger strike in 1939, De Valera was regretfully cognisant of the consequences:

He was transferred there [hospital], and got out of prison, and within a year he was engaged with others in an attack upon the Gardaí, in which two of the Gardaí were killed, and he and another party engaged in the shooting had to be executed. That meant four deaths. Later on we had two more: Two men who died on hungerstrike because we had at some stage to stand absolutely firm ... It was one of the biggest mistakes that I have made in my life ... I will regret it until my death, because, had it not been for my action, there would have been only one death, whereas, in the event, there were ... six in all. ${ }^{161}$

On 6 September 1940, McGrath and Green became the first persons to be executed by firing party since the civil war. ${ }^{162}$ The government may have refused to recognise Republican prisoners as 'members of a military force' or to accede to their demands to be held in 'military custody', but all Republicans executed under the Emergency Powers legislation were granted a 'soldier's death'. ${ }^{163}$ Death by shooting was also believed to allow for a more dignified exit; in the popular mindset hanging carried with it an enduring stigma - it was the criminal's fate. A subversive group with Republican and Nazi sympathies (known as 'Cumann Naisiunta' or 'Irish Friends of Germany') based in Dublin made efforts to identify members of the firing party, and military intelligence reports show that it had been able to ascertain the name of the soldier in charge. ${ }^{164}$ Thomas Hunt was condemned a little over two weeks after the executions of his comrades. ${ }^{165}$ But he was spared. Minister for Justice Gerald Boland later divulged that he had deemed Hunt 'the sort of young fellow who got landed in it more by accident than anything else'. ${ }^{166}$

\section{CONCLUSION}

Although Michael Manning was the last person to be hanged in Ireland the courts continued to sentence convicted murderers to death. James Kelly was the last person to be so sentenced, whose conviction was not overturned on appeal. ${ }^{167}$

\footnotetext{
${ }^{160}$ Department of Justice, Memorandum, 4 Dec, 1944, NAI, DT S13567.

${ }^{161}$ Cited in Ó Longaigh, Emergency Law, 257.

${ }^{162}$ There is no entry in the Mountjoy Prison Registry of Deaths for the three IRA men who were shot there in the early 1940s (McGrath, Green and O'Neill). However, they were buried beside their comrade Charles Kerins and the governor added a diagram to Kerins's entry to show the location of the graves. In 1948 the bodies of all four were exhumed and given to their families for re-interment.

${ }^{163}$ Ó Longaigh, Emergency Law, 245.

${ }^{164}$ Extract from Weekly Miscellaneous Report - DMD, Week Ended 16 Sept. 1940, Military Archives, Cathal Brugha Barracks, G2/X/0452.

${ }^{165}$ Trials by Military Courts under Emergency Powers (No.41) Order, 1940, 16 Aug. 1940, NAI, DT S11908.

${ }^{166}$ Dáil Debates, vol.101, col.1132 (29 May 1946).

${ }^{167}$ Shan Mohangi was the last person sentenced to death before the Criminal Justice Act, 1964 came into force, but his conviction was overturned by the Court of Criminal Appeal. See The People (Attorney General) v Shan Mohangi, CCA, Unreported, 14 May 1964.
} 
On 25 May 1962, he was tried at the Central Criminal Court for the murder of a fifty-eight-year-old widow who had been found, severely injured, on the road about 300 yards from her home in County Galway. She died during the journey to hospital. The living room and bedroom of her cottage were disordered and there were splashes of blood on the walls and bed. There was evidence that she had been sexually assaulted. The accused was a thirty-year-old unemployed labourer, who had been treated for alcoholism and was in financial distress. Medical evidence suggested that Kelly had been insane for at least four years; that he was an 'aggressive psychopath'. ${ }^{168}$ The jury concluded that he was sane and convicted him of murder.

Despite the horrific nature of Kelly's crime and against a background of rising homicide, ${ }^{169}$ by this stage commutation was inevitable; the Fianna Fáil government was finally taking the action required to restrict the use of capital punishment. The Criminal Justice Act, 1964 limited the death penalty to treason, a number of offences against military law, and what was termed 'capital murder'. The latter entailed killing a Garda or prison officer as well as other politically-motivated murders. A small number of people were convicted of capital murder for killing on-duty Gardaí. ${ }^{170}$ None were executed but in an eerie reminder of the past, when execution was a possibility, a Garda request was sent across the Irish Sea for the services of a hangman. ${ }^{171}$ The death penalty was abolished for all crimes in 1990 and replaced with a minimum period of forty years' imprisonment for anyone convicted of what had previously been termed capital murder. ${ }^{172}$

It is apt to conclude by returning to one of the opening themes of this essay, namely the belief that if the public had been given a chance in the post-Independence period they would have denied the Irish state the power to kill convicted killers. This was belatedly put to the test in a referendum that took place in 2001 to remove all references to the death penalty from the Constitution and to prohibit its reintroduction. An international survey carried out before the debate about constitutional prohibition got underway revealed that support for capital punishment in Ireland was among the lowest in the world. ${ }^{173}$ Ireland was a more confident state at this time and the peace process in Northern Ireland meant that the threat of subversion had been dramatically reduced, and with it one of the traditional justifications for capital punishment. Also, across the developed world - with the notable exceptions of the USA and Japan - de

\footnotetext{
${ }^{168}$ The People (Attorney General) v James Kelly, CCA No.33 of 1962, Unreported, 14 May 1964.

${ }^{169}$ I. O'Donnell, 'Violence and Social Change in the Republic of Ireland', 32 International Journal of the Sociology of Law (2005), 102-117.

${ }^{170}$ Noel Callan and Michael McHugh were the last persons to be sentenced to death under the 1964 legislation. They killed Garda Sergeant Paddy Morrissey on 27 June 1985 and their sentences were commuted by the president, Patrick Hillery, to forty years' imprisonment.

${ }^{171}$ Request from the Garda (Republic of Ireland police) to the Metropolitan Police Special Branch (instead of through Government channels) for the services of an executioner, 1 Jan. 1976-31 Dec. 1976, NAUK, HO $325 / 84$.

${ }^{172}$ Criminal Justice Act, 1990, s.4.

${ }^{173}$ In Taiwan, support for the death penalty stood at 83 per cent, compared with 68 per cent in the USA, 50 per cent in the UK and 17 per cent in Ireland. Only in Norway (16 per cent) and Iceland (13 per cent) was there a lower level of public support. J. Unnever, 'Global Support for the Death Penalty', 12 Punishment and Society (2010), 473-474.
} 
jure abolition was becoming the norm. ${ }^{174}$ The referendum campaign excited little controversy and resulted in an emphatic rejection of capital punishment. ${ }^{175}$ Whether this put Ireland in the way of once again becoming the 'Island of Saints', as our petitioner predicted at the outset of this essay, is for others to judge.

\footnotetext{
${ }^{174}$ Hood and Hoyle, The Death Penalty, 31-32. For an account of why state killing persists in the USA, see D. Garland, Peculiar Institution: America's Death Penalty in an Age of Abolition, New York, 2010. On Japan, see D. Johnson, 'Where the State Kills in Secret: Capital Punishment in Japan', 8 Punishment and Society (2006), 251-285.

${ }^{175}$ The turnout was 35 per cent with almost two-thirds (62 per cent) voting in favour of the proposed amendment.
} 